\title{
Obesity-related hypertension: possible pathophysiological mechanisms
}

\author{
Ivana Vaněčková, Lenka Maletínská', Michal Behuliak, Veronika Nagelová', \\ Josef Zicha and Jaroslav Kuneš
}

Institute of Physiology, Academy of Sciences of the Czech Republic v.v.i., Videnska 1083, 14220 Prague 4, Czech Republic

${ }^{1}$ Institute of Organic Chemistry and Biochemistry, Academy of Sciences of the Czech Republic v.v.i., Prague, Czech Republic
Correspondence should be addressed to J Kuneš

Email

kunes@biomed.cas.cz

\begin{abstract}
Hypertension is one of the major risk factors of cardiovascular diseases, but despite a century of clinical and basic research, the discrete etiology of this disease is still not fully understood. The same is true for obesity, which is recognized as a major global epidemic health problem nowadays. Obesity is associated with an increasing prevalence of the metabolic syndrome, a cluster of risk factors including hypertension, abdominal obesity, dyslipidemia, and hyperglycemia. Epidemiological studies have shown that excess weight gain predicts future development of hypertension, and the relationship between BMI and blood pressure (BP) appears to be almost linear in different populations. There is no doubt that obesity-related hypertension is a multifactorial and polygenic trait, and multiple potential pathogenetic mechanisms probably contribute to the development of higher BP in obese humans. These include hyperinsulinemia, activation of the renin-angiotensin-aldosterone system, sympathetic nervous system stimulation, abnormal levels of certain adipokines such as leptin, or cytokines acting at the vascular endothelial level. Moreover, some genetic and epigenetic mechanisms are also in play. Although the full manifestation of both hypertension and obesity occurs predominantly in adulthood, their roots can be traced back to early ontogeny. The detailed knowledge of alterations occurring in the organism of experimental animals during particular critical periods (developmental windows) could help to solve this phenomenon in humans and might facilitate the age-specific prevention of human obesity-related hypertension. In addition, better understanding of particular pathophysiological mechanisms might be useful in so-called personalized medicine.
\end{abstract}

\author{
Key Words \\ > obesity \\ - hypertension \\ sympathetic nervous system \\ - renin-angiotensin system \\ - critical developmental \\ periods \\ - epigenetics
}

- rat
Journal of Endocrinology (2014) 223, R63-R78

\section{Introduction}

There is no doubt that the prevalence of obesity and the associated cardiovascular diseases has increased dramatically around the world in the last decade. Current assessment indicates that more than one billion people in the world are overweight or obese (Yach et al. 2006,
Aguilera et al. 2013). It is estimated that the annual medical burden of obesity and obesity-related diseases costs hundreds of billions of US dollars in the United States alone (Landsberg et al. 2013) and this trend has an increasing tendency. International studies on the

Published by Bioscientifica Ltd. 
economic costs of obesity have shown that they account for $2-7 \%$ of total health care costs, the level of which depends on the way the analysis is performed (WHO 2000).

Although the relationship between obesity and hypertension is widely recognized, there is a question as to what is the primary abnormality? It has been suggested that obesity is characterized by a cascade of metabolic and cardiovascular disorders, including hypertension, which is a primary risk factor of obesity-induced cardiovascular disease. Epidemiological studies have demonstrated that overweight predicts future development of hypertension, and the relationship between BMI and blood pressure (BP) appears to be almost linear in different populations (Hall 2003). It seems that this relation exists already at the age of 8-11 years (Falaschetti et al. 2010). According to Third National Health and Nutrition Survey (NHANES III), the risk of hypertension has significantly increased in men and women with overweight and it was much higher for subjects with obesity (Must et al. 1999). The data from 30 years of follow-up of the original Framingham Study have demonstrated that obesity is an additional independent cardiovascular risk factor to BP (Stokes et al. 1989). Moreover, recently, it has been shown that obesity is one of the major determinants of hypertension in the general population (Kannel 2000). A similar conclusion was obtained in the Tecumseh Study (Julius et al. 2000), where BP, waist/hip ratio, and plasma insulin were elevated to a higher extent in the hypertensive group. The authors proposed a plausible hypothesis that the weight gain and $\mathrm{BP}$ elevation may be intermediate phenotypes of an underlying sympathetic overactivity in hypertension. The association between the family history of essential hypertension and body weight gain was documented by Allemann et al. (2001). Healthy normotensive 25 -year-old age- and sex-matched male offspring of hypertensive parents were matched for BP with those of normotensive parents. Five years later, the resting BP was still the same in both groups but body weight, BMI, and waist/hip ratio increased more in the offspring of hypertensive parents. The familial predisposition to hypertension and greater body weight gain is also supported by the fact that lean subjects with hypertension are about $2-3 \mathrm{~kg}$ heavier than age- and sex-matched normotensives, suggesting a link between the mechanisms that elevate BP and those that stimulate food consumption or lower energy expenditure.

The first explanation of basic mechanisms involved in the relation between human obesity and hypertension was published by Vague (1956). He noted that cardiovascular and metabolic complications of obesity were more common in patients with 'android' type of obesity (upper body obesity) when compared with 'gynoid' type (lower body obesity). Later on, several studies demonstrated the association of android (or central) obesity, hypertension, and insulin resistance, which formed the basis for understanding the pathophysiology of obesity-related hypertension (Kissebah et al. 1982, Kalkhoff et al. 1983, Modan et al. 1985, for review see Landsberg et al. (2013)).

Most recent clinical studies on the morbidities of obesity indicate that the excess weight gain by fat accumulation is not necessarily a determinant for the development of obesity-related diseases, but the abnormal body fat distribution is a more important factor for the morbidity (Matsuzawa et al. 2011, Di Chiara et al. 2012). Visceral adiposity may have a major role in the occurrence of hypertension, diabetes mellitus, hyperlipidemia, and atherosclerosis not only in obese humans but also in animal models of diet-induced obesity (Davy \& Orr 2009, Hall et al. 2010). Recent evidence revealed several biological and genetic differences between intraabdominal visceral fat and peripheral subcutaneous fat. Such differences are also reflected in their contrasting roles in the pathogenesis of obesity-related cardiometabolic problems (Hamdy et al. 2006). The functional differences between visceral and subcutaneous adipocytes may be related to their anatomical location. Visceral adipose tissue and its adipose tissue-resident macrophages produce more proinflammatory cytokines, such as tumor necrosis factor alpha (TNF $\alpha$ ) and interleukin 6 (IL6), but less adiponectin. These cytokine changes induce insulin resistance and play a major role in the pathogenesis of endothelial dysfunction and the subsequent atherosclerosis. The rate of visceral fat accumulation is also different according to the gender and ethnic background, being more prominent in white men, African American women, and Asian Indian and Japanese men and women (Hiuge-Shimizu et al. 2012). Such differences may explain the variation in the cardiometabolic risk between different populations. However, it is unclear as to what degree of visceral fat reduction is needed to induce favorable metabolic changes. The increasing knowledge about body fat distribution and its modifiers may lead to the development of more effective treatment strategies for subjects at a high risk for type 2 diabetes and coronary artery disease. It is interesting that visceral obesity elicits greater activation of the sympathetic nervous system (SNS) than subcutaneous obesity does (Grassi et al. 2004); however, the mechanism by which visceral obesity is more active in SNS activation is not clear.

The obesity-related hypertension is a multifactorial and polygenic trait (Aghamohammadzadeh \& Heagerty 2012).

Published by Bioscientifica Ltd 
The multiple potential mechanisms contribute to the development of higher BP in obese humans including hyperinsulinemia, activation of the renin-angiotensinaldosterone system, SNS stimulation, abnormal levels of certain adipokines such as leptin, and altered spectrum of cytokines acting at the vascular endothelial level (da Silva et al. 2009, Hall et al. 2010, Lambert et al. 2010). Moreover, the role of perivascular adipose tissue damage, defined as a disturbance in normal metabolic and vasoactive function of the adipocytes surrounding blood vessels, is also considered (Aghamohammadzadeh \& Heagerty 2012). However, the exact mechanisms of the relationship between obesity and hypertension are still not fully understood. Undoubtedly, the interaction of genetic and environmental factors is also important (Kuneš \& Zicha 2006). In the last years, several genetic loci and genes linked to obesity and hypertension were disclosed on different chromosomes and the list of obesity-associated loci is increasing day-by-day (Russo et al. 2010).

The influence of dietary factors on the development of obesity-related hypertension may be partially explained by epigenetics. These non-genetic alterations, which have an important regulatory action in modifying gene expression in response to environmental stimuli, are under the control of two major epigenetic mechanisms: methylation of cytosine residues of DNA and modification of histone proteins associated with DNA (chromatin remodeling). The epigenetic chromatin remodeling is very important because it modifies the accessibility of chromatin to transcription factors, facilitating the recognition of these factors by genes to be expressed and by genes to be silenced, either transiently or permanently (Spotswood \& Turner 2002). It has been demonstrated that the disruption of balance of epigenetic networks may cause several major diseases. However, the relevance of epigenetics to obesity, hypertension, and/or metabolic syndrome is less clear (Egger et al. 2004, Gallou-Kabani \& Junien 2005). We can speculate that obesity-related hypertension develops as a consequence of 'errors' in well-coordinated regulatory systems (Kuneš \& Zicha 2009). The errors in the cascade of molecular, biochemical, and genetic processes, which regulate BP, glucose metabolism, food intake, etc., have finally enough potential to result in a particular disease. As these errors may not be robust and affect various parts of the complex regulatory system, their determination might be difficult (Kuneš \& Zicha 2009).

This short review summarizes contemporary information on the pathophysiology of obesity-related hypertension. Special attention will be paid to the role of the SNS and the renin-angiotensin system (RAS) and the role of ontogenetic factors in obesity-related hypertension will be discussed. We have repeatedly emphasized the importance of age in the pathogenesis of experimental hypertension (Zicha et al. 1986, Zicha \& Kuneš 1999, Kuneš $\&$ Zicha 2006). Moreover, the hypothesis of the fetal origins of adult diseases in humans was proposed by Barker \& Osmond (1988), suggesting that environmental factors, mainly nutrition, can lead to permanent metabolic and structural changes in the fetus, thus increasing the risk of many diseases in adulthood, including hypertension (Kuneš et al. 2012) and obesity (Taylor \& Poston 2007). The knowledge of molecular mechanisms, by which early minor environmental stimuli modify the expression of genetic information, might be the desired key for the understanding of mechanisms leading to the change of phenotype in adulthood (Kuneš \& Zicha 2009, Kuneš et al. 2012). We would also like to discuss some information about epigenetic inheritance, which should partially explain the gene-environment interaction.

\section{Rat models of obesity and hypertension}

Animal models are essential to understand the pathophysiology of human diseases; however, the ideal model, which should mimic all pathophysiological features of a particular disease, does not exist. Such a model should be genetically well defined, should be large enough for experimental techniques, economically acceptable, and would develop end-stage disease comparable to that in humans (Zicha \& Kuneš 1999, Russell \& Proctor 2006). Although the mouse seems to be a more appropriate tool for genetic manipulations, its small size is not good for long-term physiological measurements. Therefore, rat models are the most useful. Spontaneous mutations and selective breeding procedures in rats provide several complementary models of obesity, hyperlipidemia, insulin resistance, and type 2 diabetes, as well as cardiovascular diseases including hypertension (Russell \& Proctor 2006, Fellmann et al. 2013). Although each animal model has some limitations and strengths, used together in a complementary fashion they are essential for the research on metabolic and cardiovascular diseases. As mentioned above, the etiology of these diseases is complex, both inherited and acquired (Kuneš \& Zicha 2006, Varga et al. 2010).

The development of obesity and the associated metabolic complications due to increased caloric intake in rodents is a widely used approach, which is parallel to human obesity. Both rat and mouse strains susceptible to the development of obesity are fed a high-fat diet (HFD) over a period of 3-4 months (Vickers et al. 2011,

Published by Bioscientifica Ltd 
Fellmann et al. 2013). Within rat strains, Wistar and Sprague-Dawley strains are most often used. However, only some Sprague-Dawley rats fed a HFD develop obesity, dyslipidemia, and arterial hypertension (Dobrian et al. 2000).

Spontaneously hypertensive rats (SHRs) are considered to be a model of essential human hypertension without obesity. However, it has been demonstrated that a HFD increased body weight, serum cholesterol, and BP in SHRs and the changes in metabolic parameters were associated with cardiovascular dysfunction in these animals (Šedová et al. 2004, Cao et al. 2011). Chung et al. (2010) have shown that after 12 weeks on the HFD, SHRs gained more body weight, their systolic BP was further elevated, and glucose intolerance induced, but there were no significant differences in the insulin resistance index, serum lipid profile, plasma renin activity, and serum aldosterone levels. On the other hand, Knight et al. (2008) observed that HFD consumption for 10 weeks had no effect on systolic BP of SHRs. It seems that the discrepant results may be due to different durations of the experiment, different ages at which HFD feeding was started, and/or different compositions of the diets.

Other models, similar to obese strain of SHR (SHROB) or Zucker rats, provide interesting results in the study of obesity-related hypertension. In 1973, Koletsky isolated a new mutation in a rat line originating from a cross between Sprague-Dawley rats and SHRs. Animals of this strain were hypertensive and became highly obese, hyperlipidemic, and hyperinsulinemic. Most interestingly, obese rats developed cardiovascular disease with atherosclerosis and advanced lesions, including dissecting aortic aneurysms (Koletsky 1975). The strain, now designated as SHROB, has been recently used as a model that closely mimicks human metabolic syndrome. Several substrains of SHROB rats with diverse severity of symptoms are used (Russell \& Proctor 2006, de Artiñano $\&$ Castro 2009). SHROB rats can be identified as obese at about 5 weeks of age together with hyperinsulinemia, slightly elevated blood glucose (Friedman et al. 1997), and insulin resistance (Velliquette et al. 2002). Spontaneous hypertension usually occurs at $\sim 3$ months of age and rises progressively; animals also develop cardiac hypertrophy and vascular disease (Ernsberger et al. 2007). Thus, one can say that obesity precedes hypertension, but it is difficult to say that obesity is a cause of hypertension in this model.

Obese Zucker rats (OZRs) are the best known and most widely used animal model of genetic obesity and hypertension, which was initially described by Zucker \& Zucker (1961) (Kurtz et al. 1989). This strain has a spontaneous mutation of the gene for leptin receptor. Leptin is a hormone released from adipocytes and acts as a key regulator of energy homeostasis. Zucker rats develop severe obesity associated with hyperphagia, defective thermogenesis and a range of endocrinological abnormalities, and insulin resistance with mild glucose intolerance, but without a progression to diabetes (Russell \& Proctor 2006, de Artiñano \& Castro 2009). Moreover, it has been demonstrated that in adult OZRs, renal and splanchnic sympathetic nerve activity (SNA) as well as mean arterial pressure (MAP) are elevated in comparison with agematched lean Zucker rats (LZRs) (Morgan et al. 1995, Huber \& Schreihofer 2010). Furthermore, it has been suggested that the elevated SNA and MAP in OZRs could be derived from the rostral ventrolateral medulla (Huber \& Schreihofer 2011). Zucker diabetic fatty (ZDF) rats are a variant of the Zucker rats, which were developed from the original Zucker colony (Friedman et al. 1991). Obese male rats of this colony were found to become diabetic, with impaired insulin secretion, but with preserved sensitivity to insulin. They also developed a late increase in systolic BP (at 7 months of age), and hence they could be considered as a good model of obesity-related hypertension (Kurtz et al. 1989). However, it should be noted that leptin receptor mutation is extremely rare in humans (Hall et al. 2001). Thus, the results from the studies on Zucker rats cannot be simply applied to human obesity, which is commonly polygenic (Bell et al. 2005).

\section{Peptides in cardiovascular regulation}

To prevent obesity-related cardiovascular disease, it is important to clarify the mechanisms controlling food intake and to determine whether these mechanisms are also involved in BP regulation. Some peptides participating in the regulation of appetite or feeding behavior seem to have a role also in cardiovascular and sympathetic regulations. These peptides include short-term centrally released and centrally acting neuropeptide Y (NPY), corticotrophin-releasing hormone $(\mathrm{CRH})$, agouti-related protein (AgRP), alpha-melanocyte-stimulating hormone $(\alpha-\mathrm{MSH})$, cocaine- and amphetamine-regulated transcript (CART) peptides, melanin-concentrating hormone $(\mathrm{MCH})$, orexins, etc. Their central effects are combined with those of peripherally released and centrally acting leptin and ghrelin, which regulate energy balance in a long-term manner, and with short-term acting peptides such as cholecystokinin (CCK) (for review see Matsumura et al. (2003), Baltatzi et al. (2008) and Sartor (2013)). Peripherally released hormones play a role in short-term

Published by Bioscientifica Ltd 
cardiovascular regulation via the vagally mediated sympathoinhibitory reflex mechanism, similar to that of the arterial baroreflex (Sartor 2013).

Leptin, the product of the $o b$ gene, is synthesized in the adipose tissue and serum leptin levels correlate with total fat mass. Leptin regulates energy intake and expenditure providing the information to the CNS and influencing the effects of other neuropeptides to decrease food intake and to upregulate thermogenesis and energy expenditure through the stimulation of SNA. These effects are mediated by two major pathways, positive regulation of anorexigenic $\alpha$-MSH and negative regulation of NPY having an orexigenic effect combined with a reduction of thermogenesis (Kotsis et al. 2010). In obesity, leptin resistance and hyperleptinemia develop because of disrupted signaling in leptin receptor-containing neurons in brain areas involved in food intake regulation, namely the hypothalamic nucleus arcuatus. Leptin action in the nucleus arcuatus is also important for the control of sympathetic outflow to both brown adipose tissue and the kidney (Rahmouni \& Morgan 2007). Selective resistance to the metabolic actions of leptin seems to be present in obesity, whereas its action in stimulation of sympathetic tone remains unaltered (Mark et al. 2004). SNS-stimulating effects of leptin are mainly demonstrated in the kidney, adrenal gland, and brown adipose tissue. Hyperleptinemia and leptin resistance thus may be the cause of chronically elevated SNS in obesity via activation of leptin receptors in hypothalamus and brainstem (Hall et al. 2010, Canale et al. 2013). In diet-induced obesity in mice, anorexigenic activity of leptin, both peripherally or centrally administered, was attenuated while renal SNA to leptin as well as increased BP were preserved, leading to hypertension (Rahmouni et al. 2005a).

Many studies have also examined whether the effects of leptin on metabolism, apoptosis, and hypertrophy could contribute to the obesity-related hypertension (for review see Sweeney (2010)). Moreover, in the leptinresistant state, NPY is overexpressed and it is released from neural sites by sympathetic activation and acts as a vasoconstrictor and thus could play a role in obesityrelated hypertension (Kotsis et al. 2010).

CCK is an anorexigenic gastrointestinal peptide with many functions related to digestion including satiety. Leptin is also released from the gastric epithelial cells of the stomach (Bado et al. 1998). Both hormones have an additive effect at the level of vagal afferents to regulate food intake, but CCK and leptin also have an interactive relationship in cardiovascular regulation via central mechanisms (Sartor 2013). The potential importance of
CCK and its receptor CCK1 has been demonstrated in rats lacking CCK1 receptors, which develop obesity, diabetes, cardiac disease, and hypertension (Yagi et al. 1997).

Ghrelin, together with leptin, is a key regulator of energy balance. It is a physiological antagonist of leptin and also acts in the hypothalamus with the opposite influence on neuropeptides such as NPY and $\alpha$-MSH compared with leptin. Although ghrelin production is known to be suppressed in obesity states, high levels of ghrelin have been found in obese hypertensive patients (Zhang et al. 2010). The relationship among obesity, hypertension, and ghrelin needs further elucidation. The exact BP-lowering mechanisms exerted by ghrelin are unknown but probably involve central and peripheral pathways. Modulation of endothelial function may be at least partially responsible for the antihypertensive actions of ghrelin. BP-lowering effect of i.v. ghrelin administration in rats occurred together with a decrease in SNA and was not caused by the direct ghrelin action on blood vessels (Callaghan et al. 2012). Moreover, a novel vascular receptor different from ghrelin receptor GHS-R1a was proposed to be involved in lowering of BP after the activation with growth hormone secretagogue analogs or ghrelin agonists in rats (Callaghan et al. 2014). In addition, it has been demonstrated that the calcium-activated potassium channel may play a key role in the BP-lowering effect of ghrelin especially in situations of endothelial dysfunction (Shinde et al. 2005).

\section{The role of SNS}

Increased SNA is a characteristic feature of many animal models of obesity (Kassab et al. 1995, Rahmouni et al. 2005a, Prior et al. 2010). High SNA has also been demonstrated in human obesity (Grassi et al. 1995, Vaz et al. 1997, Wofford et al. 2001) in which acute systemic ganglionic blockade lowers BP and peripheral resistance more in normotensive obese subjects than in lean subjects (Shibao et al. 2007). There is a considerable heterogeneity of regional SNA in obese subjects (Vaz et al. 1997; Fig. 1). Increased SNA detected in various vascular beds of obese subjects need not have the same importance for obesityrelated hypertension. Thus, substantially enhanced muscle SNA in normotensive obese subjects does not cause the increase in forearm vascular resistance because vasodilator response of $\alpha$-adrenergic blockade was similar in obese and lean subjects (Agapitov et al. 2008). On the other hand, moderately increased renal SNA seems to be of greater importance for the development of obesity-related hypertension (Hall et al. 2010). The enhancement of renal

Published by Bioscientifica Ltd. 


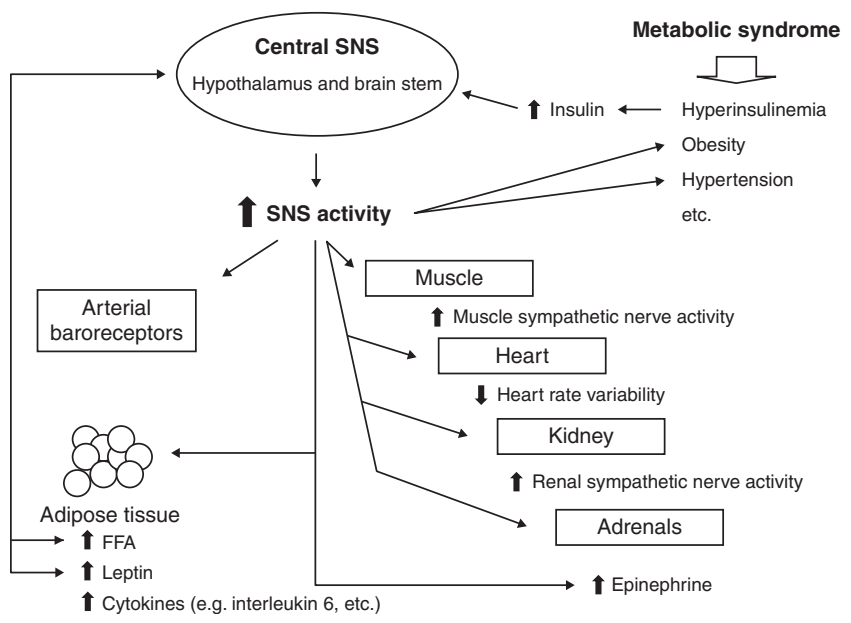

Figure 1

Particular metabolic and other effects of SNS activation.

SNA due to the impairment of baroreflex function precedes BP rise in rabbits with diet-induced obesity (Armitage et al. 2012). Moreover, renal denervation attenuated sodium retention and prevented BP rise in dogs with diet-induced obesity (Kassab et al. 1995). Similarly, chronic $\alpha$ - and $\beta$-adrenergic blockade lowered BP more in obese subjects than in lean hypertensive subjects (Wofford et al. 2001). The importance of renal sympathetic effects on obesity suggests a possible role of a recently described pathway, which is based upon norepinephrine stimulation of $\beta_{2}$-adrenergic receptors leading through suppression of serine-threonine protein kinase WNK4 to the activation of $\mathrm{Na}-\mathrm{Cl}$ cotransporter in the distal tubule. This $\beta_{2}-\mathrm{WNK} 4-\mathrm{NCC}$ pathway is responsible for sodium retention and $\mathrm{BP}$ elevation in salt hypertension (Mu et al. 2011).

Increased levels of circulating leptin and insulin as well as decreased levels of ghrelin and adiponectin were proposed to contribute to the enhancement of SNA in obesity, but impaired baroreflex sensitivity and brain RAS must also be considered (da Silva et al. 2014). One of the most important mechanisms for the induction of sympathoexcitation is the action of leptin on hypothalamic pro-opiomelanocortin (POMC) neurons (Carlyle et al. 2002, da Silva et al. 2004, Tallam et al. 2006, do Carmo et al. 2014). Brain RAS is a necessary prerequisite for leptininduced sympathetic activation (Hilzendeger et al. 2012). Leptin stimulation of its receptors in POMC neurons (located in the nucleus arcuatus and/or dorsal and ventral medial hypothalamic nuclei) causes the activation of melanocortin receptor 4 (MC4R), which is mediated by $\alpha$-MSH released from POMC neurons. MC4R antagonism lowers BP of SHRs to the same extent as $\alpha$-adrenergic blockade (da Silva et al. 2008). Moreover, normotensive LZRs respond to MC4R antagonism by a smaller BP decrease than hypertensive OZRs (do Carmo et al. 2012).

In normal animals, central leptin action is associated with decreased appetite, increased energy expenditure, body weight reduction, and sympathetic activation, whereas obese animals are characterized by selective leptin resistance that attenuates metabolic but not sympathetic response to leptin (Mark 2013). The concept of selective leptin resistance (Mark et al. 1999, 2002, Correia et al. 2002, Rahmouni et al. 2002, 2005a) is based upon the fact that yellow agouti obese mice and diet-induced obese mice were resistant to food intake and body weight effects of systemic leptin administration while leptininduced renal sympathetic activation was preserved. It means that increased leptin levels in obese animals or subjects stimulate renal SNA but they do not exert inhibitory effects on appetite, thermogenesis, and body weight. This is partially analogous to insulin resistance, which is also selective because high insulin levels elicited by hyperglycemia do not increase glucose uptake in tissues although they stimulate SNA (Landsberg 1986). Comparison of the two selective resistances, which share a common pathway of SNS activation, is shown in Fig. 2 . Insulin resistance was also suggested to participate in the pathogenetic mechanisms of hypertension (Rahmouni et al. 2003), but there is considerable evidence against its major role in obesity (Hall et al. 1990, Rocchini et al. 2004).

As far as selective leptin resistance is concerned, there is an idea (Kalil \& Haynes 2012) that increased thermogenic SNA and decreased food intake are caused by leptin action

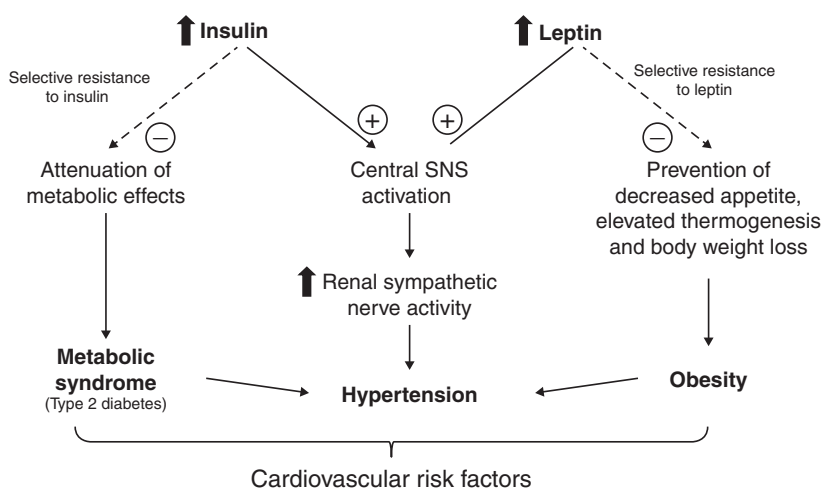

Figure 2

Selective resistance to insulin (metabolic syndrome) or leptin (obesity) the relation to sympathetic nervous system (SNS) hyperactivity and high blood pressure.

Published by Bioscientifica Ltd. 
in the nucleus arcuatus, whereas the enhanced renal SNA is due to leptin stimulation of dorsal and ventral medial hypothalamic nuclei. Another idea is that the stimulation of hypothalamic leptin receptors activates several intracellular signaling pathways including STAT3, PI3K, and MAPK (Kalil \& Haynes 2012), but only the PI3K signaling pathway is capable of activating renal SNA (Mark 2013). A further important feature of selective leptin resistance is that baroreflex activation attenuates leptininduced renal SNA, but leptin-induced sympathetic output to thermogenic tissues is not inhibited by baroreflex, thus indicating the independence of renal and thermogenic SNAs (Hausberg et al. 2002, Kalil \& Haynes 2012). The importance of baroreflex control of SNA is underlined by the effects of chronic baroreflex activation in dogs with diet-induced obesity, which caused major renal and systemic sympathoinhibition leading to BP reduction, decrease in plasma norepinephrine and renin levels as well as to lower glomerular filtration but increased fractional sodium excretion. BP changes induced by chronic baroreflex activation were comparable to those induced by renal denervation in the dogs fed the same HFD (Lohmeier et al. 2012).

The analysis of heart rate variability (HRV) in obese subjects indicates that HRV is inversely related to BMI (Laederach-Hofmann et al. 2000, Tentolouris et al. 2003). In most studies, the low-frequency/high-frequency (LF/HF) ratio (an index of the sympathovagal balance) was found to be increased in obese subjects in the fasting state, suggesting a predominance of SNS activity (Tentolouris et al. 2003). Furthermore, parasympathetic activity was reduced in obese subjects compared with lean subjects (Laederach-Hofmann et al. 2000). The diminished HRV in obese individuals might indicate either reduced receptor responsiveness or postreceptor alterations involving the cardiac sinus node. However, the power of the lowfrequency component of the HRV seems to provide an index of the baroreflex modulation of SNS activity. Hence, a reduced power of the low-frequency component of the HRV could reflect diminished baroreflex sensitivity to the changes in BP (Piccirillo et al. 1998). Such a diminished responsiveness has been confirmed by other studies using the measurements of postganglionic muscle SNA in response to the changes in MAP elicited by stepwise i.v. nitroprusside or phenylephrine infusions (Grassi et al. 1995). They have demonstrated that baseline BP and heart rate as well as plasma norepinephrine levels were similar in obese and control subjects. However, muscle SNA was more than twice higher in obese patients. Furthermore, cardiovagal baroreflex gain was found to be lower in subjects with higher abdominal visceral fat as well as in those with higher total body fat (Beske et al. 2002).

Sympathetic activity is altered by food intake; it consistently decreases after energy restriction in both animals and humans and it is activated by overfeeding (Julius et al. 2000). It is well known that fasting lowers sympathetic activity in rats and that the ingestion of sucrose solutions increases sympathetic activity in mice (Young \& Landsberg 1980). There is a highly significant inverse relationship between sympathetic activity and spontaneous food intake (Sakaguchi et al. 1988). The inverse relationship between SNA and food intake is of considerable interest, because it suggests a potential feedback loop between sympathetic activity and food intake (Bray 2000). The reciprocal relationship between food intake and sympathetic activity is robust, suggesting that $\beta$-adrenergic receptors in the periphery and brain may be involved in the control of food intake in humans. Thus, the inhibition of feeding by activating the SNS might be an important satiety system, which helps to regulate body fat stores and the obesity. However, this is rather difficult for patients who are taking $\beta$-blockers in the treatment of hypertension. An increase in body weight has been shown to occur during both short-term (Townsend \& Klein 1997) and long-lasting (Lithell et al. 1992) therapies with $\beta$-blockers. The increase in body weight caused by this therapy could be a result of their negative effects on thermogenesis and/or decreased physical activity of treated patients. Propranolol administration to hypertensive subjects significantly lowers heat production rate in skeletal muscles by $\sim 25 \%$. Moreover, body weight gain after $\beta$-blocker therapy might be also due to a decreased physical activity.

\section{Renin-angiotensin system}

The RAS is generally accepted as an important regulator of water and electrolyte balance and thus BP. Apart from the systemic RAS, locally acting RAS has been identified in different organs, including brain, pancreas, kidney, heart, and also adipose tissue (Paul et al. 2006). Locally acting RAS contains all components of RAS, including angiotensinogen (Agt), renin, and angiotensin-converting enzyme (ACE) together with $\mathrm{AT}_{1}$ and $\mathrm{AT}_{2}$ receptors (Cassis et al. 2008) to produce the main effector of the system, angiotensin II (Ang II). While Agt is produced mainly in the liver of lean individuals, adipose tissue is another important source of Agt in obese individuals (Yasue et al. 2010). The specific feature of adipose tissue RAS is its ability to produce Ang II not only via the renin and ACE

Published by Bioscientifica Ltd 
pathway but also through cathepsins and chymase (Karlsson et al. 1998). The fact that particular components of RAS are expressed in multiple tissues, including adipose tissue, suggests that this system may be associated with hypertension and obesity.

Formerly, adipose tissue has been considered only as a store for excess energy. At present, it is well recognized that adipocytes exert various physiological functions, including BP control (through Agt production) (Thatcher et al. 2009, Kalupahana \& Moustaid-Moussa 2012). Moreover, they synthesize various hormones with homeostatic function (adipokines). The localization of Agt mRNA expression in adipose tissue was disclosed by Campbell \& Habener (1987) and Cassis et al. (1988). They demonstrated it in perivascular adipose tissue surrounding the rat aorta as well as in periatrial and periaortic rat brown adipose tissue respectively. The importance of adipose Agt has been substantiated by Massiéra et al. (2001) in transgenic mice overexpressing Agt in adipocytes on a WT or Agt-deficient background. They found detectable circulating Agt concentration in Agt-deficient mice with Agt expressed only in adipocytes and these mice were normotensive. By contrast, in WT mice, the transgenic overexpression of adipocyte Agt not only increased circulating Agt concentration but also increased BP. By contrast, mice with deleted adipocyte Agt had a lower BP than their WT counterparts (Yiannikouris et al. 2012a). Not surprisingly, Agt mRNA expression levels were higher in visceral adipose tissue of Sprague-Dawley rats with dietinduced obesity and hypertension (Boustany et al. 2004). In addition, losartan treatment ( $\mathrm{AT}_{1}$ receptor blocker) was more effective in obesity-prone Sprague-Dawley rats than in obesity-resistant Sprague-Dawley rats, in which hypertension was induced by a HFD (Boustany et al. 2005). In humans, obesity is associated with increased plasma and adipose tissue Agt, renin, ACE, and Ang II, showing both systemic and adipose tissue overactivity of RAS. Importantly, body weight loss in humans has led to the lowering of the RAS overactivity (Engeli et al. 2005).

Recently, Yiannikouris et al. (2012b) have evaluated the importance of adipose tissue RAS in the development of obesity-related hypertension using a low-fat diet and a HFD. They found that a HFD induced increase in BP only in WT mice, while there was no increase in BP in mice lacking the Agt gene only in adipocytes. Interestingly, mice of both types gained weight similarly and had similar amounts of fat mass on a HFD. The most interesting finding of this study was similar plasma Agt protein levels in WT and knock-out mice, which is in contrast with the previously accepted hypothesis that the increased adipose tissue Agt gene expression is responsible for high plasma Agt levels and the activation of systemic RAS in obesity. However, plasma Ang II level was increased in WT mice fed a HFD but not in knock-out mice. Thus, whether this could be a link explaining the effect of local adipose RAS on the synthesis of circulating Ang II remains yet to be determined.

Obesity also leads to a shift of adipose tissue immune cells such as macrophages to pro-inflammatory status, causing hypertrophy of adipocytes and changes in the proportion of immune cell populations. A HFD induced adipose tissue inflammation and activation of adipocyte RAS, suggesting a role for Ang II in this process (Rahmouni et al. 2005b). In line with this finding there is the activation of pro-inflammatory cytokines (TNF $\alpha$, IL6, and IL1) by Ang II in adipocytes as demonstrated by in vitro studies.

\section{Early-life origins of disease}

The hypothesis on the fetal origins of adult diseases in humans was proposed by Barker \& Osmond (1988), who suggested that environmental factors, mainly nutrition, can lead to permanent metabolic and structural changes in the fetus and thus can increase the risk of many diseases in adulthood. Recently, we have summarized the importance of critical developmental periods in the pathogenesis of hypertension (Kuneš et al. 2012). We believe that some basic characteristics of hypertension development can be applied for the development of other significant diseases. It is also very important to take into consideration that developmental changes need not be detected immediately after the intervention. A certain delay is always present, so that one can speak about the 'late consequences of early alterations'. There is no doubt that the critical developmental periods are much better recognized and characterized in experimental animals than in humans (Zicha \& Kuneš 1999, Kuneš et al. 2012). However, as mentioned earlier, this theory can also be applied in humans. In 1986, David Barker and his colleagues postulated that the geographical distribution of mortality rates from stroke and cardiovascular diseases in 1968-1978 was closely related to the neonatal mortality in 1921-1925, suggesting that poor health and physique of mothers were the important determinants of the risk of stroke in their babies (Barker \& Osmond 1986). Later on, they reported that BP in adulthood was related not only to the birth weight but also inversely to the placental weight (Barker et al. 1990), leading to the formulation of the 'early or fetal

Published by Bioscientifica Ltd 
origin' hypothesis. Thus, the intrauterine period might be a major critical period for human diseases.

The detailed review of 48 papers clearly documented the relationship between early growth and the later occurrence of insulin resistance, type 2 diabetes, hypertension, hyperlipidemia, and cardiovascular diseases in both men and women in distinct populations in the UK, Asia, Europe, Africa, and the USA (Newsome et al. 2003). The combination of low birth weight followed by obesity in later life appears to carry the highest risk of insulin resistance.

It has been demonstrated that fetal overexposure to maternal glucocorticoids in both humans and animals triggers programming events in utero (Langley-Evans 1996, 2006, Nyirenda \& Seckl 1998). Glucocorticoids are powerful modulators of gene expression and experimental studies have demonstrated that they accelerate fetal organ maturation. This has been proposed as a key step in nutritional programming. The administration of synthetic glucocorticoids, which are poor substrates of $11 \beta$-hydroxysteroid dehydrogenase type 2, programs hypertension and renal defects in animals (Benediktsson et al. 1993, Dodic et al. 2002). Feeding of a low-protein diet to rats during pregnancy reduces both the activity and mRNA expression of placental 11ß-hydroxysteroid dehydrogenase type 2 (Langley-Evans et al. 1996, Bertram et al. 2001). Moreover, the blockade of maternal glucocorticoid synthesis through pharmacological adrenalectomy prevents the programming of hypertension in the offspring of rats fed a low-protein diet, demonstrating the glucocorticoid dependence of the nutritional effect (Langley-Evans et al. 1996, Langley-Evans 1997, McMullen \& Langley-Evans 2005). This is also true for humans in whom exogenous glucocorticoids retard fetal and placental growth and result in lower birth weight (Hofmann et al. 2001). This is corroborated by the fact that there are strong correlations among birth weight, plasma cortisol concentrations, and the development of hypertension and type 2 diabetes (Phillips et al. 2000). As perinatal exposure to glucocorticoids increases the activity of hypothalamic-pituitary-adrenal axis (Holmes et al. 2003, Bouret 2009), it has been proposed that the programming of this axis in utero is linked to behavioral modifications and neurological responses, as well as endocrine and cardiovascular functions.

Accumulating body of evidence demonstrated that leptin production from the placenta and fetal adipose tissue can regulate fetal growth and development (Stocker et al. 2005). Besides the regulation of energy balance and neuroendocrine functions in mature animals, this is another function of leptin. Administration of leptin during pregnancy and lactation to protein-restricted dams produced offspring that had increased metabolic rate and thus they were not obese when fed a HFD in adulthood (Stocker et al. 2005). This is probably due to the fact that neonatal leptin is an important trophic factor for the development of hypothalamic circuits (Bouret 2009). The existence of the critical periods for the developmental effects of leptin during key periods of hypothalamic development may induce long-lasting effects on the metabolism in adults.

\section{Epigenetic mechanisms}

Despite the enormous progress in genetic and genomic studies, including extensive analysis of the human genome, only up to $10 \%$ of discovered gene functions are known and many more remain yet to be discovered. It is evident that genetics alone cannot explain the occurrence of phenotypic heterogeneity of cardiovascular diseases including hypertension and obesity. Probably, the interaction of organism with environmental factors is dependent on several other features such as epigenetics. Epigenetics is not based upon changes in nucleotide sequence of DNA, but it is associated with DNA methylation, histone modifications, and chromatin remodeling. More than 100 modifications of histones including acetylation, methylation, phosphorylation, etc., have been described (Kouzarides 2007). Although the function of most of these 'marks' remains obscure, there is a possibility that they determine which genes are transcribed in which cells under specific circumstances. It has been shown that unusually dense collections of $\mathrm{CpG}$ dinucleotides known as CpG islands exist throughout the genome (Eckhardt et al. 2006). These islands are localized in promoter regions of particular genes and they are not methylated during transcription. Additionally, the chromatin proteins associated with DNA may be activated or silenced. This explains why the differentiated cells in a multicellular organism express only those genes that are necessary for their own activity.

There is no doubt that gene-environment interactions play a significant role in the etiology of obesity-related hypertension and other diseases. One would expect that the environmental impact (diet, lifestyle, working conditions, smoking, various infectious agents, etc.) on genetic information is exerted via DNA damage, but epigenetic inheritance seems to be more responsible (Kuneš \& Zicha 2006). Several recent studies have demonstrated how environmental factors can modify

Published by Bioscientifica Ltd 
epigenetic processes, thereby affecting epigenetic marks and downstream patterns of gene expression in specific cells and cell lineages (Roche et al. 2005, Gluckman et al. 2007, Waterland \& Michels 2007, Feinberg 2008). Epigenetic changes not only occur in the course of individual organism's lifetime, but also may be inherited from one generation to the next. It seems that environmental conditions influencing the organism during its lifetime may activate specific silent alleles or suppress others. The epigenome is a connection between environmental exposure and gene expression, thus influencing cell/tissue function. This may be especially important for the early life (in utero) exposure. In the earliest stages of life, the genome undergoes radical changes in epigenetic marks, which are characterized by waves of demethylation of DNA followed by remethylation (Reik et al. 2001). These imprinting patterns, if not erased after fertilization, may become stable and persist to the next generations of experimental animals (Zambrano et al. 2005, Pinheiro et al. 2008, Torrens et al. 2008) and even of humans (Veenendaal et al. 2013). This can be reversed by the changes in lifestyle (Gallou-Kabani \& Junien 2005). For example, it was observed that protein restriction during pregnancy of rats can result in hypomethylation of peroxisome proliferator-activated receptor alpha (Lillycrop et al. 2008), hepatic glucocorticoid receptor promoters (Lillycrop et al. 2005), and angiotensin $\mathrm{AT}_{1 \mathrm{~b}}$ receptor in the offspring (Bogdarina et al. 2007). Intrauterine exposure to a low-protein diet may increase the risk of hypertension also by the increased corticosteroid levels. The transgenerational effects could be triggered through environmental factors such as food preferences, special dietetic factors, and physical activity. For example, in the agouti mouse model, folate supplementation of the maternal diet at conception augments DNA methylation of the agouti gene and increases longevity of the offspring (Cooney et al. 2002).

Recently, it has been shown that complex diseases such as obesity or hypertension may be related to highly interconnected gene networks and core network modules that are deregulated by susceptibility loci (Emilsson et al. 2008, Mehler 2008). Moreover, not only gene networks but also environmental factors and epigenome, more complex networks can collaborate in clinical manifestations of specific disease states (Fig. 3). On the basis of animal models of disease as well as of human clinical trials, there are currently three classes of epigenetic therapies i) DNA methylation inhibitors, ii) histone deacetylase (HDAC) inhibitors, and iii) RNA-based approaches (Ptak \& Petronis 2008).

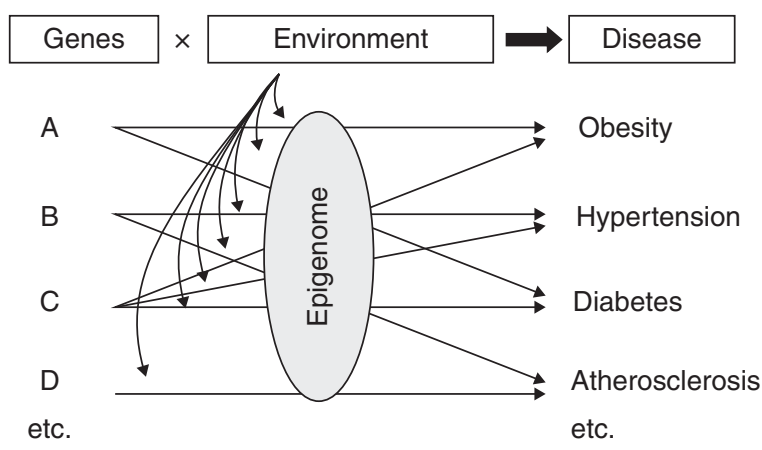

Figure 3

The interaction of genes, environment, and epigenome in the etiology of polygenic diseases.

The study of epigenetic and developmental processes could shed new light on serious health problems. For example, protein restriction in pregnant rats reduces methylation of the promoter region of the gene that codes for glucocorticoid receptor in offspring liver cells (Lillycrop et al. 2007, Erhuma et al. 2009). This leads to the amplification of the liver metabolic response to stress hormones. Moreover, it has been demonstrated that pups of rat mothers on a low-protein diet overexpress the $\mathrm{AT}_{1 \mathrm{~b}}$ receptor $\mathrm{mRNA}$ and protein in the adrenal gland, suggesting its contribution to the elevated BP observed in these animals (Bogdarina et al. 2007). The expression of $\mathrm{AT}_{1 \mathrm{a}}$ receptor was normal. However, such results cannot be simply transferred into human pathology because human genome contains only a single $\mathrm{AT}_{1}$ receptor gene, which is widely expressed in a pattern similar to that of $\mathrm{AT}_{1 \mathrm{a}}$ receptor in rodents (Inagami 1995). Besides the role of the prenatal environment, including nutrition, the effects of prenatal stress and social environmental exposures can be important factors (Darnaudéry \& Maccari 2008, Kuzawa \& Sweet 2009). Therefore, the study of epigenetic contributions to obesity-related hypertension and other cardiovascular diseases should be very important for the understanding of other regulatory mechanisms and for the development of new therapeutic strategies as mentioned in several recent reviews (Wong et al. 2005, Turunen et al. 2009, Ordovás \& Smith 2010, Lillycrop \& Burdge 2012).

\section{Conclusions}

Obesity-related hypertension is an important medical problem. According to the epidemiological studies, we can talk about the pandemic of obesity and thus partially also about the epidemic of hypertension. Obesity-related hypertension is a chronic, slowly developing disease the

Published by Bioscientifica Ltd. 


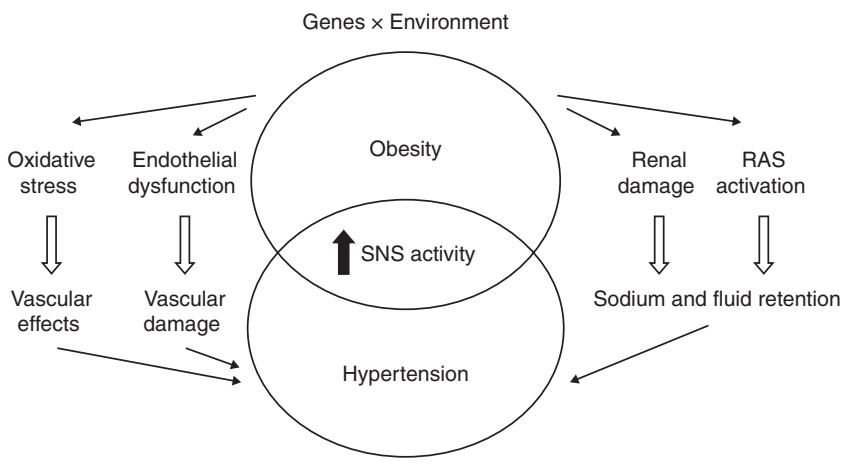

Figure 4

Relation between obesity and hypertension as well as particular mechanisms by which obesity may cause hypertension.

pathology of which is complex, and multiple potential mechanisms could play a role in the relation between obesity and hypertension (Fig. 4). Despite the fact that many details about the development and maintenance of obesity-related hypertension have been identified, the primary impulse to start the pathological process is still not known, and neither is it known whether obesity causes hypertension or vice versa. Nevertheless, it has been demonstrated (Messerli et al. 1981) that obesity per se raises BP by only a few millimeters of mercury, while $50 \%$ of individuals with hypertensive obesity have a much larger rise in BP (Korner 2007).

Gene-environment interactions are gaining more and more attention in the etiology of human diseases. There is an increasing belief that epigenetic variants and inheritance could provide the missing piece of a puzzle for the understanding of these very complicated relationships in many diseases, which have usually the complex phenotypes, e.g. obesity-related hypertension. Studies on genetic association have had a mixed success in the detection of important genes and/or environmental influences that are notoriously difficult to identify. Thus, epigenetic changes and regulation become increasingly important. The research community is increasingly aware of the role that chromatin plays in gene regulation, transcription, and disease development.

However, once the obesity-related hypertension has developed, the complete normalization of BP is difficult, if not impossible. The main concern for the future should be therefore the prevention of obesity and/or hypertension development as well as the personalized medicine. There is no doubt that the young organism is highly sensitive to various risk factors and it may also be more sensitive to various pharmacological interventions than the adult one.
Therefore, the early diagnosis of obesity, hypertension, and other diseases together with the change in lifestyle can lead to early intervention and thereby can improve the health of the whole population. However, the question whether obesity prevention will reduce hypertension and vice versa remains yet to be clarified. The proper understanding of the important mechanisms in obesity-related hypertension and other complex diseases in experimental animals together with the precise determination of the critical developmental periods for the onset of these diseases might be the first step toward the development of new therapies in human medicine.

\section{Declaration of interest}

The authors declare that there is no conflict of interest that could be perceived as prejudicing the impartiality of the review.

\section{Funding}

This work was supported in part by RVO: 67985823, RVO: 61388963, and research grant GACR 304/12/0259.

\section{References}

Agapitov AV, Correia ML, Sinkey CA \& Haynes WG 2008 Dissociation between sympathetic nerve traffic and sympathetically mediated vascular tone in normotensive human obesity. Hypertension 52 687-695. (doi:10.1161/HYPERTENSIONAHA.107.109603)

Aghamohammadzadeh R \& Heagerty AM 2012 Obesity-related hypertension: epidemiology, pathophysiology, treatments, and the contribution of perivascular adipose tissue. Annals of Medicine 44(Suppl 1) S74-S84. (doi:10.3109/07853890.2012.663928)

Aguilera CM, Olza J \& Gil A 2013 Genetic susceptibility to obesity and metabolic syndrome in childhood. Nutrición Hospitalaria 28(Suppl 5) 44-55.

Allemann Y, Hutter D, Aeschbacher BC, Fuhrer J, Delacrétaz E \& Weidmann P 2001 Increased central body fat deposition precedes a significant rise in resting blood pressure in male offspring of essential hypertensive parents: a 5 year follow-up study. Journal of Hypertension 19 2143-2148. (doi:10.1097/00004872-200112000-00005)

Armitage JA, Burke SL, Prior LJ, Barzel B, Eikelis N, Lim K \& Head GA 2012 Rapid onset of renal sympathetic nerve activation in rabbits fed a highfat diet. Hypertension 60 163-171. (doi:10.1161/HYPERTENSIONAHA. 111.190413)

de Artiñano A \& Castro M 2009 Experimental rat models to study the metabolic syndrome. British Journal of Nutrition 102 1246-1253. (doi:10.1017/S0007114509990729)

Bado A, Levasseur S, Attoub S, Kermorgant S, Laigneau JP, Bortoluzzi MN, Moizo L, Lehy T, Guerre-Millo M, Le Marchand-Brustel Y et al. 1998 The stomach is a source of leptin. Nature 394 790-793. (doi:10.1038/29547)

Baltatzi M, Hatzitolios A, Tziomalos K, Iliadis F \& Zamboulis C 2008 Neuropeptide $\mathrm{Y}$ and $\alpha$-melanocyte-stimulating hormone: interaction in obesity and possible role in the development of hypertension. International Journal of Clinical Practice 62 1432-1440. (doi:10.1111/ j.1742-1241.2008.01823.x)

Barker DJ \& Osmond C 1986 Infant mortality, childhood nutrition, and ischaemic heart disease in England and Wales. Lancet 1 1077-1081. (doi:10.1016/S0140-6736(86)91340-1) http://joe.endocrinology-journals.org DOI: 10.1530/JOE-14-0368
C 2014 Society for Endocrinology Printed in Great Britain 
Barker DJ \& Osmond C 1988 Low birth weight and hypertension. BMJ 297 134-135. (doi:10.1136/bmj.297.6641.134-b)

Barker DJ, Bull AR, Osmond C \& Simmonds SJ 1990 Fetal and placental size and risk of hypertension in adult life. BMJ 301 259-262. (doi:10.1136/ bmj.301.6746.259)

Bell CG, Walley AJ \& Froguel P 2005 The genetics of human obesity. Nature Reviews. Genetics 6 221-234. (doi:10.1038/nrg1556)

Benediktsson R, Lindsay RS, Noble J, Seckl JR \& Edwards CR 1993 Glucocorticoid exposure in utero: new model for adult hypertension. Lancet 341 339-341. (doi:10.1016/0140-6736(93)90138-7)

Bertram C, Trowern AR, Copin N, Jackson AA \& Whorwood CB 2001 The maternal diet during pregnancy programs altered expression of the glucocorticoid receptor and type $211 \beta$-hydroxysteroid dehydrogenase: potential molecular mechanisms underlying the programming of hypertension in utero. Endocrinology 142 2841-2853. (doi:10.1210/en. 142.7.2841)

Beske SD, Alvarez GE, Ballard TP \& Davy KP 2002 Reduced cardiovagal baroreflex gain in visceral obesity: implications for the metabolic syndrome. American Journal of Physiology. Heart and Circulatory Physiology 282 H630-H635. (doi:10.1152/ajpheart.00642.2001)

Bogdarina I, Welham S, King PJ, Burns SP \& Clark AJ 2007 Epigenetic modification of the renin-angiotensin system in the fetal programming of hypertension. Circulation Research 100 520-526. (doi:10.1161/01. RES.0000258855.60637.58)

Bouret SG 2009 Early life origins of obesity: role of hypothalamic programming. Journal of Pediatric Gastroenterology and Nutrition 48(Suppl 1) S31-S38. (doi:10.1097/MPG.0b013e3181977375)

Boustany CM, Bharadwaj K, Daugherty A, Brown DR, Randall DC \& Cassis LA 2004 Activation of the systemic and adipose renin-angiotensin system in rats with diet-induced obesity and hypertension. American Journal of Physiology. Regulatory, Integrative and Comparative Physiology $\mathbf{2 8 7}$ R943-R949. (doi:10.1152/ajpregu.00265.2004)

Boustany CM, Brown DR, Randall DC \& Cassis LA 2005 AT1-receptor antagonism reverses the blood pressure elevation associated with dietinduced obesity. American Journal of Physiology. Regulatory, Integrative and Comparative Physiology 289 R181-R186. (doi:10.1152/ajpregu.00507.2004)

Bray GA 2000 Reciprocal relation of food intake and sympathetic activity: experimental observations and clinical implications. International Journal of Obesity and Related Metabolic Disorders 24(Suppl 2) S8-S17. (doi:10.1038/sj.ijo.0801269)

Callaghan B, Hunne B, Hirayama H, Sartor DM, Nguyen TV, Abogadie FC, Ferens D, McIntyre P, Ban K, Baell J et al. 2012 Sites of action of ghrelin receptor ligands in cardiovascular control. American Journal of Physiology. Heart and Circulatory Physiology 303 H1011-H1021. (doi:10.1152/ ajpheart.00418.2012)

Callaghan B, Kosari S, Pustovit RV, Sartor DM, Ferens D, Ban K, Baell J, Nguyen TV, Rivera LR, Brock JA et al. 2014 Hypotensive effects of ghrelin receptor agonists mediated through a novel receptor. British Journal of Pharmacology 171 1275-1286. (doi:10.1111/bph.12527)

Campbell DJ \& Habener JF 1987 Cellular localization of angiotensinogen gene expression in brown adipose tissue and mesentery: quantification of messenger ribonucleic acid abundance using hybridization in situ. Endocrinology 121 1616-1626. (doi:10.1210/endo-121-5-1616)

Canale MP, Manca di Villahermosa S, Martino G, Rovella V, Noce A, De Lorenzo A \& Di Daniele N 2013 Obesity-related metabolic syndrome: mechanisms of sympathetic overactivity. International Journal of Endocrinology 2013 865965. (doi:10.1155/2013/865965)

Cao J, Sodhi K, Puri N, Monu SR, Rezzani R \& Abraham NG 2011 High fat diet enhances cardiac abnormalities in SHR rats: protective role of heme oxygenase-adiponectin axis. Diabetology \& Metabolic Syndrome 337. (doi:10.1186/1758-5996-3-37)

Carlyle M, Jones OB, Kuo JJ \& Hall JE 2002 Chronic cardiovascular and renal actions of leptin: role of adrenergic activity. Hypertension 39 496-501. (doi:10.1161/hy0202.104398)

do Carmo JM, da Silva AA, Rushing JS \& Hall JE 2012 Activation of the central melanocortin system contributes to the increased arterial

http://joe.endocrinology-journals.org DOI: 10.1530/JOE-14-0368
() 2014 Society for Endocrinology Printed in Great Britain pressure in obese Zucker rats. American Journal of Physiology. Regulatory, Integrative and Comparative Physiology 302 R561-R567. (doi:10.1152/ ajpregu.00392.2011)

do Carmo JM, da Silva AA, Sessums PO, Ebaady SH, Pace BR, Rushing JS, Davis MT \& Hall JE 2014 Role of Shp2 in forebrain neurons in regulating metabolic and cardiovascular functions and responses to leptin. International Journal of Obesity 38 775-783. (doi:10.1038/ijo.2013.177)

Cassis LA, Lynch KR \& Peach MJ 1988 Localization of angiotensinogen messenger RNA in rat aorta. Circulation Research 62 1259-1262. (doi:10.1161/01.RES.62.6.1259)

Cassis LA, Police SB, Yiannikouris F \& Thatcher SE 2008 Local adipose tissue renin-angiotensin system. Current Hypertension Reports 10 93-98. (doi:10.1007/s11906-008-0019-9)

Chung S, Park CW, Shin SJ, Lim JH, Chung HW, Youn DY, Kim HW, Kim BS, Lee JH, Kim GH et al. 2010 Tempol or candesartan prevents high-fat diet-induced hypertension and renal damage in spontaneously hypertensive rats. Nephrology, Dialysis, Transplantation 25 389-399. (doi:10.1093/ndt/gfp472)

Cooney CA, Dave AA \& Wolff GL 2002 Maternal methyl supplements in mice affect epigenetic variation and DNA methylation of offspring. Journal of Nutrition 132 2393S-2400S.

Correia ML, Haynes WG, Rahmouni K, Morgan DA, Sivitz WI \& Mark AL 2002 The concept of selective leptin resistance: evidence from agouti yellow obese mice. Diabetes 51 439-442. (doi:10.2337/ diabetes.51.2.439)

Darnaudéry M \& Maccari S 2008 Epigenetic programming of the stress response in male and female rats by prenatal restraint stress. Brain Research Reviews 57 571-585. (doi:10/1016/j.brainresrev.2007.11.004)

Davy KP \& Orr JS 2009 Sympathetic nervous system behavior in human obesity. Neuroscience and Biobehavioral Reviews 33 116-124. (doi:10.1016/j.neubiorev.2008.05.024)

Di Chiara T, Argano C, Corrao S, Scaglione R \& Licata G 2012 Hypoadiponectinemia: a link between visceral obesity and metabolic syndrome. Journal of Nutrition and Metabolism 2012175245. (doi:10.1155/2012/175245)

Dobrian AD, Davies MJ, Prewitt RL \& Lauterio TJ 2000 Development of hypertension in a rat model of diet-induced obesity. Hypertension $\mathbf{3 5}$ 1009-1015. (doi:10.1161/01.HYP.35.4.1009)

Dodic M, Hantzis V, Duncan J, Rees S, Koukoulas I, Johnson K, Wintour EM \& Moritz K 2002 Programming effects of short prenatal exposure to cortisol. FASEB Journal 16 1017-1026. (doi:10.1096/fj.01-1045com)

Eckhardt F, Lewin J, Cortese R, Rakyan VK, Attwood J, Burger M, Burton J, Cox TV, Davies R, Down TA et al. 2006 DNA methylation profiling of human chromosomes 6, 20 and 22. Nature Genetics 38 1378-1385. (doi:10.1038/ng1909)

Egger G, Liang G, Aparicio A \& Jones PA 2004 Epigenetics in human disease and prospects for epigenetic therapy. Nature $\mathbf{4 2 9} 457-463$. (doi:10.1038/nature02625)

Emilsson V, Thorleifsson G, Zhang B, Leonardson AS, Zink F, Zhu J, Carlson S, Helgason A, Walters GB, Gunnarsdottir S et al. 2008 Genetics of gene expression and its effect on disease. Nature 452 423-428. (doi:10.1038/nature06758)

Engeli S, Böhnke J, Gorzelniak K, Janke J, Schling P, Bader M, Luft FC \& Sharma AM 2005 Weight loss and the renin-angiotensin-aldosterone system. Hypertension 45 356-362. (doi:10.1161/01.HYP.0000154361. 47683.d3)

Erhuma A, McMullen S, Langley-Evans SC \& Bennett AJ 2009 Feeding pregnant rats a low-protein diet alters the hepatic expression of SREBP1c in their offspring via a glucocorticoid-related mechanism. Endocrine 36 333-338. (doi:10.1007/s12020-009-9225-8)

Ernsberger P, Johnson JL, Rosenthal T, Mirelman D \& Koletsky RJ 2007 Therapeutic actions of allylmercaptocaptopril and captopril in a rat model of metabolic syndrome. American Journal of Hypertension 20 866-874. (doi:10.1016/j.amjhyper.2007.02.015)

Falaschetti E, Hingorani AD, Jones A, Charakida M, Finer N, Whincup P, Lawlor DA, Davey Smith G, Sattar N \& Deanfield JE 2010 Adiposity and 
cardiovascular risk factors in a large contemporary population of pre-pubertal children. European Heart Journal 31 3063-3072. (doi:10.1093/eurheartj/ehq355)

Feinberg AP 2008 Epigenetics at the epicenter of modern medicine. Journal of the American Medical Association 299 1345-1350. (doi:10.1001/jama.299.11.1345)

Fellmann L, Nascimento AR, Tibiriça E \& Bousquet P 2013 Murine models for pharmacological studies of the metabolic syndrome. Pharmacology \& Therapeutics 137 331-340. (doi:10.1016/j.pharmthera.2012.11.004)

Friedman JE, de Venté JE, Peterson RG \& Dohm GL 1991 Altered expression of muscle glucose transporter GLUT-4 in diabetic fatty Zucker rats (ZDF/Drt-fa). American Journal of Physiology 261 E782-E788.

Friedman JE, Ishizuka T, Liu S, Farrell CJ, Bedol D, Koletsky RJ, Kaung HL \& Ernsberger P 1997 Reduced insulin receptor signaling in the obese spontaneously hypertensive Koletsky rat. American Journal of Physiology 273 E1014-E1023.

Gallou-Kabani C \& Junien C 2005 Nutritional epigenomics of metabolic syndrome: new perspective against the epidemic. Diabetes 54 1899-1906. (doi:10.2337/diabetes.54.7.1899)

Gluckman PD, Lillycrop KA, Vickers MH, Pleasants AB, Phillips ES, Beedle AS, Burdge GC \& Hanson MA 2007 Metabolic plasticity during mammalian development is directionally dependent on early nutritional status. PNAS 104 12796-12800. (doi:10.1073/pnas.0705667104)

Grassi G, Seravalle G, Cattaneo BM, Bolla GB, Lanfranchi A, Colombo M, Giannattasio C, Brunani A, Cavagnini F \& Mancia G 1995 Sympathetic activation in obese normotensive subjects. Hypertension 25 560-563. (doi:10.1161/01.HYP.25.4.560)

Grassi G, Dell'Oro R, Facchini A, Quarti Trevano F, Bolla GB \& Mancia G 2004 Effect of central and peripheral body fat distribution on sympathetic and baroreflex function in obese normotensives. Journal of Hypertension 22 2363-2369. (doi:10.1097/00004872-200412000-00019)

Hall JE 2003 The kidney, hypertension, and obesity. Hypertension 41 625-633. (doi:10.1161/01.HYP.0000052314.95497.78)

Hall JE, Brands MW, Kivlighn SD, Mizelle HL, Hildebrandt DA \& Gaillard CA 1990 Chronic hyperinsulinemia and blood pressure. Interaction with catecholamines? Hypertension 15 519-527. (doi:10.1161/01.HYP.15.5.519)

Hall JE, Hildebrandt DA \& Kuo J 2001 Obesity hypertension: role of leptin and sympathetic nervous system. American Journal of Hypertension 14 103S-115S. (doi:10.1016/S0895-7061(01)02077-5)

Hall JE, da Silva AA, do Carmo JM, Dubinion J, Hamza S, Munusamy S, Smith G \& Stec DE 2010 Obesity-induced hypertension: role of sympathetic nervous system, leptin, and melanocortins. Journal of Biological Chemistry 285 17271-17276. (doi:10.1074/jbc.R110.113175)

Hamdy O, Porramatikul S \& Al-Ozairi E 2006 Metabolic obesity: the paradox between visceral and subcutaneous fat. Current Diabetes Reviews 2 367-373. (doi:10.2174/1573399810602040367)

Hausberg M, Morgan DA, Chapleau MA, Sivitz WI, Mark AL \& Haynes WG 2002 Differential modulation of leptin-induced sympathoexcitation by baroreflex activation. Journal of Hypertension 20 1633-1641. (doi:10.1097/00004872-200208000-00027)

Hilzendeger AM, Morgan DA, Brooks L, Dellsperger D, Liu X, Grobe JL, Rahmouni K, Sigmund CD \& Mark AL 2012 A brain leptin-renin angiotensin system interaction in the regulation of sympathetic nerve activity. American Journal of Physiology. Heart and Circulatory Physiology 303 H197-H206. (doi:10.1152/ajpheart.00974.2011)

Hiuge-Shimizu A, Kishida K, Funahashi T, Ishizaka Y, Oka R, Okada M, Suzuki S, Takaya N, Nakagawa T, Fukui T et al. 2012 Reduction of visceral fat correlates with the decrease in the number of obesity-related cardiovascular risk factors in Japanese with Abdominal Obesity (VACATION-J Study). Journal of Atherosclerosis and Thrombosis 19 1006-1018. (doi:10.5551/jat.12963)

Hofmann M, Pollow K, Bahlmann F, Casper F, Steiner E \& Brockerhoff P

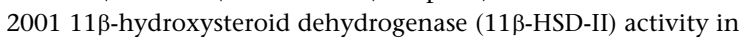
human placenta: its relationship to placental weight and birth weight and its possible role in hypertension. Journal of Perinatal Medicine 29 23-30. (doi:10.1515/JPM.2001.003)
Holmes MC, Yau JL, Kotelevtsev Y, Mullins JJ \& Seckl JR 2003 $11 \beta$-hydroxysteroid dehydrogenases in the brain: two enzymes two roles. Annals of the New York Academy of Sciences 1007 357-366. (doi:10.1196/annals.1286.035)

Huber DA \& Schreihofer AM 2010 Attenuated baroreflex control of sympathetic nerve activity in obese Zucker rats by central mechanisms. Journal of Physiology 588 1515-1525. (doi:10.1113/jphysiol.2009. 186387)

Huber DA \& Schreihofer AM 2011 Altered regulation of the rostral ventrolateral medulla in hypertensive obese Zucker rats. American Journal of Physiology. Heart and Circulatory Physiology 301 H230-H240. (doi:10.1152/ajpheart.00075.2011)

Inagami T 1995 Recent progress in molecular and cell biological studies of angiotensin receptors. Current Opinion in Nephrology and Hypertension 4 47-54. (doi:10.1097/00041552-199501000-00007)

Julius S, Valentini M \& Palatini P 2000 Overweight and hypertension: a 2-way street? Hypertension 35 807-813. (doi:10.1161/01.HYP.35.3.807)

Kalil GZ \& Haynes WG 2012 Sympathetic nervous system in obesity-related hypertension: mechanisms and clinical implications. Hypertension Research 35 4-16. (doi:10.1038/hr.2011.173)

Kalkhoff RK, Hartz AH, Rupley D, Kissebah AH \& Kelber S 1983 Relationship of body fat distribution to blood pressure, carbohydrate tolerance, and plasma lipids in healthy obese women. Journal of Laboratory and Clinical Medicine 102 621-627.

Kalupahana NS \& Moustaid-Moussa N 2012 The renin-angiotensin system: a link between obesity, inflammation and insulin resistance. Obesity Reviews 13 136-149. (doi:10.1111/j.1467-789X.2011.00942.x)

Kannel WB 2000 Fifty years of Framingham Study contributions to understanding hypertension. Journal of Human Hypertension 14 83-90. (doi:10.1038/sj.jhh.1000949)

Karlsson C, Lindell K, Ottosson M, Sjöström L, Carlsson B \& Carlsson LM 1998 Human adipose tissue expresses angiotensinogen and enzymes required for its conversion to angiotensin II. Journal of Clinical Endocrinology and Metabolism 83 3925-3929. (doi:10.1210/jc.83. 11.3925)

Kassab S, Kato T, Wilkins FC, Chen R, Hall JE \& Granger JP 1995 Renal denervation attenuates the sodium retention and hypertension associated with obesity. Hypertension 25 893-897. (doi:10.1161/01. HYP. 25.4.893)

Kissebah AH, Vydelingum N, Murray R, Evans DJ, Hartz AJ, Kalkhoff RK \& Adams PW 1982 Relation of body fat distribution to metabolic complications of obesity. Journal of Clinical Endocrinology and Metabolism 54 254-260. (doi:10.1210/jcem-54-2-254)

Knight SF, Quigley JE, Yuan J, Roy SS, Elmarakby A \& Imig JD 2008 Endothelial dysfunction and the development of renal injury in spontaneously hypertensive rats fed a high-fat diet. Hypertension $\mathbf{5 1}$ 352-359. (doi:10.1161/HYPERTENSIONAHA.107.099499)

Koletsky S 1975 Pathologic findings and laboratory data in a new strain of obese hypertensive rats. American Journal of Pathology 80 129-142.

Korner PI 2007 Essential Hypertension and Its Causes: Neural and Non-Neural Mechanisms, pp 408-409. Oxford: Oxford University Press.

Kotsis V, Stabouli S, Papakatsika S, Rizos Z \& Parati G 2010 Mechanisms of obesity-induced hypertension. Hypertension Research 33 386-393. (doi:10.1038/hr.2010.9)

Kouzarides T 2007 Chromatin modifications and their function. Cell 128 693-705. (doi:10.1016/j.cell.2007.02.005)

Kuneš J \& Zicha J 2006 Developmental windows and environment as important factors in the expression of genetic information: a cardiovascular physiologist's view. Clinical Science $111295-305$. (doi:10.1042/CS20050271)

Kuneš J \& Zicha J 2009 The interaction of genetic and environmental factors in the etiology of hypertension. Physiological Research 58(Suppl 2) S33-S41.

Kuneš J, Kadlecová M, Vaněčková I \& Zicha J 2012 Critical developmental periods in the pathogenesis of hypertension. Physiological Research 61(Suppl 1) S9-S17. 
Kurtz TW, Morris RC \& Pershadsingh HA 1989 The Zucker fatty rat as a genetic model of obesity and hypertension. Hypertension 13 896-901. (doi:10.1161/01.HYP.13.6.896)

Kuzawa CW \& Sweet E 2009 Epigenetics and the embodiment of race: developmental origins of US racial disparities in cardiovascular health. American Journal of Human Biology 21 2-15. (doi:10.1002/ajhb.20822)

Laederach-Hofmann K, Mussgay L \& Rúddel H 2000 Autonomic cardiovascular regulation in obesity. Journal of Endocrinology 164 59-66. (doi:10.1677/joe.0.1640059)

Lambert GW, Straznicky NE, Lambert EA, Dixon JB \& Schlaich MP 2010 Sympathetic nervous activation in obesity and the metabolic syndrome - causes, consequences and therapeutic implications. Pharmacology \& Therapeutics 126 159-172. (doi:10.1016/j.pharmthera.2010.02.002)

Landsberg L 1986 Diet, obesity and hypertension: an hypothesis involving insulin, the sympathetic nervous system, and adaptive thermogenesis. Quarterly Journal of Medicine 61 1081-1090.

Landsberg L, Aronne LJ, Beilin LJ, Burke V, Igel LI, Lloyd-Jones D \& Sowers J 2013 Obesity-related hypertension: pathogenesis, cardiovascular risk, and treatment: a position paper of The Obesity Society and the American Society of Hypertension. Journal of Clinical Hypertension 15 14-33. (doi:10.1111/jch.12049)

Langley-Evans SC 1996 Intrauterine programming of hypertension in the rat: nutrient interactions. Comparative Biochemistry and Physiology. Part A, Physiology 114 327-333. (doi:10.1016/0300-9629(96)00018-7)

Langley-Evans SC 1997 Hypertension induced by foetal exposure to a maternal low-protein diet, in the rat, is prevented by pharmacological blockade of maternal glucocorticoid synthesis. Journal of Hypertension 15 537-544. (doi:10.1097/00004872-199715050-00010)

Langley-Evans SC 2006 Developmental programming of health and disease. Proceedings of the Nutrition Society 65 97-105. (doi:10.1079/ PNS2005478)

Langley-Evans SC, Phillips GJ, Benediktsson R, Gardner DS, Edwards CR, Jackson AA \& Seckl JR 1996 Protein intake in pregnancy, placental glucocorticoid metabolism and the programming of hypertension in the rat. Placenta 17 169-172. (doi:10.1016/S0143-4004(96)80010-5)

Lillycrop KA \& Burdge GC 2012 Epigenetic mechanisms linking early nutrition to long term health. Best Practice \& Research. Clinical Endocrinology \& Metabolism 26 667-676. (doi:10.1016/j.beem. 2012.03.009)

Lillycrop KA, Phillips ES, Jackson AA, Hanson MA \& Burdge GC 2005 Dietary protein restriction of pregnant rats induces and folic acid supplementation prevents epigenetic modification of hepatic gene expression in the offspring. Journal of Nutrition 135 1382-1386.

Lillycrop KA, Slater-Jefferies JL, Hanson MA, Godfrey KM, Jackson AA \& Burdge GC 2007 Induction of altered epigenetic regulation of the hepatic glucocorticoid receptor in the offspring of rats fed a protein-restricted diet during pregnancy suggests that reduced DNA methyltransferase-1 expression is involved in impaired DNA methylation and changes in histone modifications. British Journal of Nutrition 97 1064-1073. (doi:10.1017/S000711450769196X)

Lillycrop KA, Phillips ES, Torrens C, Hanson MA, Jackson AA \& Burdge GC 2008 Feeding pregnant rats a protein-restricted diet persistently alters the methylation of specific cytosines in the hepatic PPAR $\alpha$ promoter of the offspring. British Journal of Nutrition 100 278-282. (doi:10.1017/ S0007114507894438)

Lithell H, Pollare T, Berne C \& Saltin B 1992 The metabolic and circulatory response to $\beta$-blockade in hypertensive men is correlated to muscle capillary density. Blood Pressure 1 20-26. (doi:10.3109/ 08037059209065120)

Lohmeier TE, Iliescu R, Liu B, Henegar JR, Maric-Bilkan C \& Irwin ED 2012 Systemic and renal-specific sympathoinhibition in obesity hypertension. Hypertension 59 331-338. (doi:10.1161/HYPERTENSIONAHA.111. 185074)

Mark AL 2013 Selective leptin resistance revisited. American Journal of Physiology. Regulatory, Integrative and Comparative Physiology $\mathbf{3 0 5}$ R566-R581. (doi:10.1152/ajpregu.00180.2013)
Mark AL, Shaffer RA, Correia ML, Morgan DA, Sigmund CD \& Haynes WG 1999 Contrasting blood pressure effects of obesity in leptin-deficient ob/ob mice and agouti yellow obese mice. Journal of Hypertension 17 1949-1953. (doi:10.1097/00004872-199917121-00026)

Mark AL, Correia ML, Rahmouni K \& Haynes WG 2002 Selective leptin resistance: a new concept in leptin physiology with cardiovascular implications. Journal of Hypertension 20 1245-1250. (doi:10.1097/ 00004872-200207000-00001)

Mark AL, Correia ML, Rahmouni K \& Haynes WG 2004 Loss of leptin actions in obesity: two concepts with cardiovascular implications. Clinical and Experimental Hypertension 26 629-636. (doi:10.1081/ CEH-200031948)

Massiéra F, Bloch-Faure M, Ceiler D, Murakami K, Fukamizu A, Gasc JM, Quignard-Boulange A, Negrel R, Ailhaud G, Seydoux J et al. 2001 Adipose angiotensinogen is involved in adipose tissue growth and blood pressure regulation. FASEB Journal 15 2727-2729. (doi:10.1096/ fj.01-0457fje)

Matsumura K, Tsuchihashi T, Fujii K \& Iida M 2003 Neural regulation of blood pressure by leptin and the related peptides. Regulatory Peptides 114 79-86. (doi:10.1016/S0167-0115(03)00116-2)

Matsuzawa Y, Funahashi T \& Nakamura T 2011 The concept of metabolic syndrome: contribution of visceral fat accumulation and its molecular mechanism. Journal of Atherosclerosis and Thrombosis 18 629-639. (doi:10.5551/jat.7922)

McMullen S \& Langley-Evans SC 2005 Maternal low-protein diet in rat pregnancy programs blood pressure through sex-specific mechanisms. American Journal of Physiology. Regulatory, Integrative and Comparative Physiology 288 R85-R90. (doi:10.1152/ajpregu.00435.2004)

Mehler MF 2008 Epigenetic principles and mechanisms underlying nervous system functions in health and disease. Progress in Neurobiology 86 305-341. (doi:10.1016/j.pneurobio.2008.10.001)

Messerli FH, Christie B, DeCarvalho JG, Aristimuno GG, Suarez DH, Dreslinski GR \& Frohlich ED 1981 Obesity and essential hypertension. Hemodynamics, intravascular volume, sodium excretion, and plasma renin activity. Archives of Internal Medicine 141 81-85. (doi:10.1001/ archinte.1981.00340010073016)

Modan M, Halkin H, Almog S, Lusky A, Eshkol A, Shefi M, Shitrit A \& Fuchs Z 1985 Hyperinsulinemia. A link between hypertension obesity and glucose intolerance. Journal of Clinical Investigation 75 809-817. (doi:10.1172/JCI111776)

Morgan DA, Anderson EA \& Mark AL 1995 Renal sympathetic nerve activity is increased in obese Zucker rats. Hypertension 25 834-838. (doi:10.1161/01.HYP.25.4.834)

Mu S, Shimosawa T, Ogura S, Wang H, Uetake Y, Kawakami-Mori F, Marumo T, Yatomi Y, Geller DS, Tanaka H et al. 2011 Epigenetic modulation of the renal $\beta$-adrenergic-WNK4 pathway in salt-sensitive hypertension. Nature Medicine 17 573-580. (doi:10.1038/nm.2337)

Must A, Spadano J, Coakley EH, Field AE, Colditz G \& Dietz WH 1999 The disease burden associated with overweight and obesity. Journal of the American Medical Association 282 1523-1529. (doi:10.1001/jama. 282.16.1523)

Newsome CA, Shiell AW, Fall CH, Phillips DI, Shier R \& Law CM 2003 Is birth weight related to later glucose and insulin metabolism? A systematic review Diabetic Medicine 20 339-348. (doi:10.1046/ j.1464-5491.2003.00871.x)

Nyirenda MJ \& Seckl JR 1998 Intrauterine events and the programming of adulthood disease: the role of fetal glucocorticoid exposure (Review). International Journal of Molecular Medicine 2 607-614. (doi:10.3892/ ijmm.2.5.607)

Ordovás JM \& Smith CE 2010 Epigenetics and cardiovascular disease. Nature Reviews. Cardiology 7 510-519. (doi:10.1038/nrcardio.2010.104)

Paul M, Poyan Mehr A \& Kreutz R 2006 Physiology of local reninangiotensin systems. Physiological Reviews 86 747-803. (doi:10.1152/ physrev.00036.2005)

Phillips DI, Walker BR, Reynolds RM, Flanagan DE, Wood PJ, Osmond C, Barker DJ \& Whorwood CB 2000 Low birth weight predicts elevated

Published by Bioscientifica Ltd. 
plasma cortisol concentrations in adults from 3 populations. Hypertension 35 1301-1306. (doi:10.1161/01.HYP.35.6.1301)

Piccirillo G, Vetta F, Viola E, Santagada E, Ronzoni S, Cacciafesta M \& Marigliano V 1998 Heart rate and blood pressure variability in obese normotensive subjects. International Journal of Obesity and Related Metabolic Disorders 22 741-750. (doi:10.1038/sj.ijo.0800650)

Pinheiro AR, Salvucci ID, Aguila MB \& Mandarim-de-Lacerda CA 2008 Protein restriction during gestation and/or lactation causes adverse transgenerational effects on biometry and glucose metabolism in F1 and F2 progenies of rats. Clinical Science 114 381-392. (doi:10.1042/ CS20070302)

Prior LJ, Eikelis N, Armitage JA, Davern PJ, Burke SL, Montani JP, Barzel B \& Head GA 2010 Exposure to a high-fat diet alters leptin sensitivity and elevates renal sympathetic nerve activity and arterial pressure in rabbits. Hypertension 55 862-868. (doi:10.1161/HYPERTENSIONAHA. 109.141119)

Ptak C \& Petronis A 2008 Epigenetics and complex disease: from etiology to new therapeutics. Annual Review of Pharmacology and Toxicology 48 257-276. (doi:10.1146/annurev.pharmtox.48.113006.094731)

Rahmouni K \& Morgan DA 2007 Hypothalamic arcuate nucleus mediates the sympathetic and arterial pressure responses to leptin. Hypertension 49 647-652. (doi:10.1161/01.HYP.0000254827.59792.b2)

Rahmouni K, Haynes WG, Morgan DA \& Mark AL 2002 Selective resistance to central neural administration of leptin in agouti obese mice. Hypertension 39 486-490. (doi:10.1161/hy0202.102836)

Rahmouni K, Haynes WG, Morgan DA \& Mark AL 2003 Role of melanocortin-4 receptors in mediating renal sympathoactivation to leptin and insulin. Journal of Neuroscience 23 5998-6004.

Rahmouni K, Morgan DA, Morgan GM, Mark AL \& Haynes WG $2005 a$ Role of selective leptin resistance in diet-induced obesity hypertension. Diabetes 54 2012-2018. (doi:10.2337/diabetes.54.7.2012)

Rahmouni K, Correia ML, Haynes WG \& Mark AL $2005 b$ Obesity-associated hypertension: new insights into mechanisms. Hypertension 45 9-14. (doi:10.1161/01.HYP.0000151325.83008.b4)

Reik W, Dean W \& Walter J 2001 Epigenetic reprogramming in mammalian development. Science 293 1089-1093. (doi:10.1126/science.1063443)

Rocchini AP, Yang JQ \& Gokee A 2004 Hypertension and insulin resistance are not directly related in obese dogs. Hypertension 43 1011-1016. (doi:10.1161/01.HYP.0000123073.48855.e9)

Roche HM, Phillips C \& Gibney MJ 2005 The metabolic syndrome: the crossroads of diet and genetics. Proceedings of the Nutrition Society 64 371-377. (doi:10.1079/PNS2005445)

Russell JC \& Proctor SD 2006 Small animal models of cardiovascular disease: tools for the study of the roles of metabolic syndrome, dyslipidemia, and atherosclerosis. Cardiovascular Pathology 15 318-330. (doi:10.1016/j.carpath.2006.09.001)

Russo P, Lauria F \& Siani A 2010 Heritability of body weight: moving beyond genetics. Nutrition, Metabolism, and Cardiovascular Diseases 20 691-697. (doi:10.1016/j.numecd.2010.09.007)

Sakaguchi T, Takahashi M \& Bray GA 1988 Diurnal changes in sympathetic activity. Relation to food intake and to insulin injected into the ventromedial or suprachiasmatic nucleus. Journal of Clinical Investigation 82 282-286. (doi:10.1172/JCI113584)

Sartor DM 2013 Sympathoinhibitory signals from the gut and obesity-related hypertension. Clinical Autonomic Research 23 33-39. (doi:10.1007/s10286-012-0171-9)

Šedová L, Bérubé J, Gaudet D, Dumont M, Tremblay J, Hamet P \& Pausová Z 2004 Diet-induced obesity delays cardiovascular recovery from stress in spontaneously hypertensive rats. Obesity Research 12 1951-1958. (doi:10.1038/oby.2004.245)

Shibao C, Gamboa A, Diedrich A, Ertl AC, Chen KY, Byrne DW, Farley G, Paranjape SY, Davis SN \& Biaggioni I 2007 Autonomic contribution to blood pressure and metabolism in obesity. Hypertension 49 27-33. (doi:10.1161/01.HYP.0000251679.87348.05)

Shinde UA, Desai KM, Yu C \& Gopalakrishnan V 2005 Nitric oxide synthase inhibition exaggerates the hypotensive response to ghrelin: role of calcium-activated potassium channels. Journal of Hypertension $\mathbf{2 3}$ 779-784. (doi:10.1097/01.hjh.0000163146.20330.bc)

da Silva AA, Kuo JJ \& Hall JE 2004 Role of hypothalamic melanocortin 3/4-receptors in mediating chronic cardiovascular, renal, and metabolic actions of leptin. Hypertension 43 1312-1317. (doi:10.1161/01. HYP.0000128421.23499.b9)

da Silva AA, do Carmo JM, Kanyicska B, Dubinion J, Brandon E \& Hall JE 2008 Endogenous melanocortin system activity contributes to the elevated arterial pressure in spontaneously hypertensive rats. Hypertension 51 884-890. (doi:10.1161/HYPERTENSIONAHA.107. 100636)

da Silva AA, do Carmo J, Dubinion J \& Hall JE 2009 The role of the sympathetic nervous system in obesity-related hypertension. Current Hypertension Reports 11 206-211. (doi:10.1007/s11906-009-0036-3)

da Silva AA, do Carmo JM, Wang Z \& Hall JE 2014 The brain melanocortin system, sympathetic control, and obesity hypertension. Physiology 29 196-202. (doi:10.1152/physiol.00061.2013)

Spotswood HT \& Turner BM 2002 An increasingly complex code. Journal of Clinical Investigation 110 577-582. (doi:10.1172/JCI0216547)

Stocker CJ, Arch JR \& Cawthorne MA 2005 Fetal origins of insulin resistance and obesity. Proceedings of the Nutrition Society 64 143-151. (doi:10.1079/PNS2005417)

Stokes J III, Kannel WB, Wolf PA, D'Agostino RB \& Cupples LA 1989 Blood pressure as a risk factor for cardiovascular disease. The Framingham Study - 30 years of follow-up. Hypertension 13 I13-I18. (doi:10.1161/ 01.HYP.13.5_Suppl.I13)

Sweeney G 2010 Cardiovascular effects of leptin. Nature Reviews. Cardiology 7 22-29. (doi:10.1038/nrcardio.2009.224)

Tallam LS, da Silva AA \& Hall JE 2006 Melanocortin-4 receptor mediates chronic cardiovascular and metabolic actions of leptin. Hypertension $\mathbf{4 8}$ 58-64. (doi:10.1161/01.HYP.0000227966.36744.d9)

Taylor PD \& Poston L 2007 Developmental programming of obesity in mammals. Experimental Physiology 92 287-298. (doi:10.1113/expphysiol.2005.032854)

Tentolouris N, Tsigos C, Perea D, Koukou E, Kyriaki D, Kitsou E, Daskas S, Daifotis Z, Makrilakis K, Raptis SA et al. 2003 Differential effects of highfat and high-carbohydrate isoenergetic meals on cardiac autonomic nervous system activity in lean and obese women. Metabolism 52 1426-1432. (doi:10.1016/S0026-0495(03)00322-6)

Thatcher S, Yiannikouris F, Gupte M \& Cassis L 2009 The adipose reninangiotensin system: role in cardiovascular disease. Molecular and Cellular Endocrinology 302 111-117. (doi:10.1016/j.mce.2009.01.019)

Torrens C, Poston L \& Hanson MA 2008 Transmission of raised blood pressure and endothelial dysfunction to the $\mathrm{F} 2$ generation induced by maternal protein restriction in the F0, in the absence of dietary challenge in the F1 generation. British Journal of Nutrition 100 760-766. (doi:10.1017/S0007114508921747)

Townsend RR \& Klein S 1997 Lipolytic sensitivity and response to fasting in normotensive and hypertensive obese humans. Metabolism 46 1080-1084. (doi:10.1016/S0026-0495(97)90282-1)

Turunen MP, Lehtola T, Heinonen SE, Assefa GS, Korpisalo P, Girnary R, Glass CK, Väisänen S \& Ylä-Herttuala S 2009 Efficient regulation of VEGF expression by promoter-targeted lentiviral shRNAs based on epigenetic mechanism: a novel example of epigenetherapy. Circulation Research 105 604-609. (doi:10.1161/CIRCRESAHA.109.200774)

Vague J 1956 The degree of masculine differentiation of obesities: a factor determining predisposition to diabetes, atherosclerosis, gout, and uric calculous disease. American Journal of Clinical Nutrition 4 20-34.

Varga O, Harangi M, Olsson IA \& Hansen AK 2010 Contribution of animal models to the understanding of the metabolic syndrome: a systematic overview. Obesity Reviews 11 792-807. (doi:10.1111/j.1467-789X.2009. 00667.x)

Vaz M, Jennings G, Turner A, Cox H, Lambert G \& Esler M 1997 Regional sympathetic nervous activity and oxygen consumption in obese normotensive human subjects. Circulation 96 3423-3429. (doi:10.1161/01.CIR.96.10.3423) 
Veenendaal MV, Painter RC, de Rooij SR, Bossuyt PM, van der Post JA, Gluckman PD, Hanson MA \& Roseboom TJ 2013 Transgenerational effects of prenatal exposure to the 1944-45 Dutch famine. BJOG: an International Journal of Obstetrics and Gynaecology 120 548-553. (doi:10.1111/1471-0528.12136)

Velliquette RA, Koletsky RJ \& Ernsberger P 2002 Plasma glucagon and free fatty acid responses to a glucose load in the obese spontaneous hypertensive rat (SHROB) model of metabolic syndrome X. Experimental Biology and Medicine 227 164-170.

Vickers SP, Jackson HC \& Cheetham SC 2011 The utility of animal models to evaluate novel anti-obesity agents. British Journal of Pharmacology 164 1248-1262. (doi:10.1111/j.1476-5381.2011.01245.x)

Waterland RA \& Michels KB 2007 Epigenetic epidemiology of the developmental origins hypothesis. Annual Review of Nutrition 27 363-388. (doi:10.1146/annurev.nutr.27.061406.093705)

WHO 2000 Obesity: preventing and managing the global epidemic. Report of a WHO consultation. World Health Organization Technical Report Series 894 i-xii, 1-253.

Wofford MR, Anderson DC Jr, Brown CA, Jones DW, Miller ME \& Hall JE 2001 Antihypertensive effect of $\alpha$ - and $\beta$-adrenergic blockade in obese and lean hypertensive subjects. American Journal of Hypertension $\mathbf{1 4}$ 694-698. (doi:10.1016/S0895-7061(01)01293-6)

Wong AH, Gottesman II \& Petronis A 2005 Phenotypic differences in genetically identical organisms: the epigenetic perspective. Human Molecular Genetics 14 R11-R18. (doi:10.1093/hmg/ddi116)

Yach D, Stuckler D \& Brownell KD 2006 Epidemiologic and economic consequences of the global epidemics of obesity and diabetes. Nature Medicine 12 62-66. (doi:10.1038/nm0106-62)

Yagi K, Kim S, Wanibuchi H, Yamashita T, Yamamura Y \& Iwao H 1997 Characteristics of diabetes, blood pressure, and cardiac and renal complications in Otsuka Long-Evans Tokushima Fatty rats. Hypertension 29 728-735. (doi:10.1161/01.HYP.29.3.728)
Yasue S, Masuzaki H, Okada S, Ishii T, Kozuka C, Tanaka T, Fujikura J, Ebihara K, Hosoda K, Katsurada A et al. 2010 Adipose tissue-specific regulation of angiotensinogen in obese humans and mice: impact of nutritional status and adipocyte hypertrophy. American Journal of Hypertension 23 425-431. (doi:10.1038/ajh.2009.263)

Yiannikouris F, Karounos M, Charnigo R, English VL, Rateri DL, Daugherty A \& Cassis LA 2012a Adipocyte-specific deficiency of angiotensinogen decreases plasma angiotensinogen concentration and systolic blood pressure in mice. American Journal of Physiology. Regulatory, Integrative and Comparative Physiology 302 R244-R251. (doi:10.1152/ajpregu.00323.2011)

Yiannikouris F, Gupte M, Putnam K, Thatcher S, Charnigo R, Rateri DL, Daugherty A \& Cassis LA 2012b Adipocyte deficiency of angiotensinogen prevents obesity-induced hypertension in male mice. Hypertension 60 1524-1530. (doi:10.1161/HYPERTENSIONAHA.112.192690)

Young JB \& Landsberg L 1980 Impaired suppression of sympathetic activity during fasting in the gold thioglucose-treated mouse. Journal of Clinical Investigation 65 1086-1094. (doi:10.1172/JCI109761)

Zambrano E, Martínez-Samayoa PM, Bautista CJ, Deás M, Guillén L, Rodríguez-González GL, Guzmán C, Larrea F \& Nathanielsz PW 2005 Sex differences in transgenerational alterations of growth and metabolism in progeny (F2) of female offspring (F1) of rats fed a low protein diet during pregnancy and lactation. Journal of Physiology 566 225-236. (doi:10.1113/jphysiol.2005.086462)

Zhang G, Yin X, Qi Y, Pendyala L, Chen J, Hou D \& Tang C 2010 Ghrelin and cardiovascular diseases. Current Cardiology Reviews 6 62-70. (doi:10.2174/157340310790231662)

Zicha J \& Kuneš J 1999 Ontogenetic aspects of hypertension development: analysis in the rat. Physiological Reviews 79 1227-1282.

Zicha J, Kuneš J \& Jelínek J 1986 Experimental hypertension in young and adult animals. Hypertension 8 1096-1104. (doi:10.1161/01.HYP. 8.12.1096)

Zucker LM \& Zucker TF 1961 Fatty, a new mutation in the rat. Journal of Heredity $\mathbf{5 2}$ 275-278.

Received in final form 7 October 2014

Accepted 14 October 2014 http://joe.endocrinology-journals.org

DOI: 10.1530/JOE-14-0368
() 2014 Society for Endocrinology Printed in Great Britain
Published by Bioscientifica Ltd. 